\title{
Assessment of Mobbing and Job Satisfaction Relationship in Nurses: A Systematic Review and Meta- Analysis
}

\author{
Mustafa Kurnaz $^{1}$ iD , Gülpembe 0ğuzhan² ${ }^{\text {iD }}$
}

${ }^{1}$ Econix Research Analysis and Consulting Corporation, Teknopark, Samsun, Turkey

${ }^{2}$ Department of Health Care Management, Ondokuz Mayıs University, Samsun, Turkey

Mustafa KURNAZ

Gülpembe OĞUZHAN

Correspondence: Mustafa Kurnaz Econix Research Analysis and Consulting Corporation, Teknopark, Samsun, Turkey Phone: +905057324388

E-mail: mustafa.kurnaz@windowslive.com

$\begin{array}{ll}\text { Received } & : 27 \text { January } 2021 \\ \text { Accepted } & : 15 \text { August } 2021\end{array}$

\section{ABSTRACT}

Aim: The aim of this study to examine the perceived mobbing levels, and to look into the relationship between mobbing and job satisfaction of nurses working in Turkey through a meta-analysis.

Methods: This systematic review and meta-analysis is based on the Joanna Briggs Institute guidelines. A total of 850 studies on perceived mobbing levels, and 50 studies on the relationship between mobbing and job satisfaction were retrieved from databases which are Ulusal Tez Merkezi, DergiPark, PubMed, EBSCO Host, and Web of Science. The articles and dissertations were written in Turkish and English and published before December 31, 2018. The PRISMA statement was used to report systematic review and meta-analysis.

Results: The perceived mobbing level was found to be 1.867 , and a negative and medium-level relationship was observed between mobbing and job satisfaction in nurses who work in Turkey $(r=-.510, p=.000)$.

Conclusions: The perceived mobbing level, according to the meta-analysis, were found to show that nurses are exposed to a high degree of mobbing behavior in Turkey. The relationship between mobbing and job satisfaction showed a negative and moderate correlation. In other words, as the mobbing level increases, the job satisfaction level decreases.

Keywords: nurses, job satisfaction, systematic review, meta-analysis

\section{Hemşirelerde Mobbing ve İş Tatmini İlişkisinin Meta Analiz Yöntemiyle İncelenmesi}

ÖZET

Amaç: Bu çalışmanın amacı, algılanan mobbing düzeylerini incelemek ve Türkiye'de çalışan hemşirelerin mobbing ile iş tatmini arasındaki ilişkiyi meta-analiz yöntemiyle incelemektir.

Metot: Bu sistematik inceleme ve meta-analiz Joanna Briggs Institute yönergelerine dayanmaktadır. Ulusal Tez Merkezi, DergiPark, PubMed, EBSCO Host ve Web of Science veri tabanlarından algılanan mobbing düzeyleri ile ilgili toplam 850 çalışma ve mobbing ile iş doyumu arasındaki ilişkiye yönelik 50 çalışmaya ulaşılmıştır. Türkçe ve İngilizce olarak yazıımış olan ve 31 Aralık 2018 tarihinden önce yayımlanmış makale ve tezler çalışmaya dahil edilmiştir. PRISMA ifadesi, sistematik inceleme ve meta-analizi bildirmek için kullanıımıştır.

Bulgular: Algılanan mobbing düzeyi 1.867 olarak bulunmuş ve Türkiye'de çalışan hemşirelerde mobbing ile iş doyumu arasında negatif ve orta düzeyde bir ilişki olduğu görülmüştür $(r=-.510, p=.000)$.

Sonuç: Meta-analiz sonuçlarına göre Türkiye'de hemşirelerin yüksek derecede mobbing davranışına maruz kaldığı görülmüştür. Mobbing ile iş doyumu arasındaki ilişki, negatif ve orta düzeyde bir korelasyon göstermiştir. Bu da, mobbing seviyesi arttıkça iş doyumu seviyesinin düştüğünü göstermektedir .

Anahtar Kelimeler: hemşireler, iş tatmini, sistematik inceleme, meta-analiz 
$\mathbf{N}$ egative factors such as bad management, gossip, workplace conflicts experienced in the workplace are an important problem for employees. Nowadays, an employee spends most of his/her time in the workplace and is in a business environment (1) with his/her colleagues even more than with family members. Therefore, a healthy, comfortable, and psychologically comfortable work environment becomes more important for the working individual (2). Many studies have shown that mobbing in the workplace has a negative effect on job satisfaction (2-7).

Leymann (8) defines mobbing as a "hostile and unethical form of communication systematically implemented by one or more people." In order for negative behaviors to be defined as mobbing, such behaviors must be repeated for at least six months and at least once a week. In literature, there are many definitions of mobbing. According to the points that these definitions have in common, mobbing is a repetitive and long-term negative behavior with a power imbalance between the chosen victim and the mobbing practitioner, leaving negative effects on the victim (8-13).

Due to the nature of the health sector, long-term (sometimes without work opportunities), intense, and uncomfortable work environments create more occupational risks than in other jobs (14). Although mobbing is an important risk factor for all occupational groups, it is especially common in the health sector (15-16). Due to the nature of the health sector, long-term (sometimes working without the opportunity to rest), intense and uncomfortable working environment creates more occupational risks than other jobs (14). Among the reasons for the high rate of mobbing in health institutions are; Working conditions, discrimination among patients, high number of patients, salary, shifts, not being able to spare time for family and friends in line with working conditions can be counted (17). Within health sector, nurses are those who are most exposed to mobbing (18). As a result of nurses working in environments with high levels of mobbing, their stress levels increase, their physical and psychological health fail to function properly, and, consequently, they fail to fulfill their responsibilities, their productivity decreases, and institutional functioning deteriorates (19).

Job satisfaction is defined as an effective sensation that develops based on an individual's expectations, their personal characteristics, and the interaction between employess (20). Low job satisfaction reduces the quality of work, negatively influences the social, emotional, and physical health of an employee, and causes the employee to be alienated from the job (21).

As health workers contribute to the important issue of human life, employees need to do their jobs effectively and efficiently. This depends on a high level of job satisfaction of employees (22). According to Kavak (23) if employees are mobbed, job satisfaction levels and the productivity of employees decrease.

The aim of this study is to examine the perceived mobbing levels, and to look into the relationship between mobbing and job satisfaction of nurses working in Turkey through a meta-analysis.

In this research, the answers to the following questions are sought:

1. What are the perceived mobbing levels of nurses who work in Turkey?

2. What is the level of the relationship between mobbing and job satisfaction in nurses who work in Turkey?

\section{METHOD}

Design

After gathering quantitative studies on perceived mobbing level and the relationship between mobbing and job satisfaction, a coding method was developed to convert categorical variables from appropriate studies to be included in the study. The appropriate studies were selected based on the subject of the research, the sample group, the scale used and the availability of sufficient data. The features to be coded had to have a property that would affect the effect size. The studies included in the metaanalysis had to be coded clearly and in detail (24). The form that constituted the coding method consisted of three sections:

- Study ID: This section contained the name(s), number(s), and author(s) of the research; the year and place of research; and the type of study.

- Study Content: This section contained information about the sample and the applied scale.

- Study Data: In this section, perceived mobbing level averages of the nurses, correlation values, and sample numbers were included. 
The studies to be included in the study were also checked according to the "Systematic Screening and Research Synthesis Checklist" prepared by the Joanna Briggs Institute (25) and Preferred Reporting Items for Systematic Reviews and Meta-Analyses (PRISMA) statement (see Supplementary File 1).

Since this is a meta-analysis study, ethics committee approval was not required.

\section{Search Method}

The online databases of Ulusal Tez Merkezi, DergiPark, PubMed, EBSCO Host, and Web of Science were searched. To acquire published studies thematic to perceived mobbing levels, and mobbing and job satisfaction, the search included studies that were published before December 31, 2018. See Table 1 and Table 2 for search strategies.

\begin{tabular}{|c|c|c|}
\hline Database & Search terms & $\begin{array}{l}\text { Number } \\
\text { of Articles }\end{array}$ \\
\hline Ulusal Tez Merkezi & nurse* and mobbing* & 558 \\
\hline DergiPark & nurse* and mobbing* & 265 \\
\hline PubMed & nurse* and mobbing* & 15 \\
\hline Web of Science & nurse* and mobbing* & 7 \\
\hline EBSCO Host & nurse $^{*}$ and mobbing* & 5 \\
\hline Duplicates removed & & 15 \\
\hline $\begin{array}{l}\text { Studies retained after both } \\
\text { review (YES articles) }\end{array}$ & & 6 \\
\hline $\begin{array}{l}\text { FINAL study selection (after } \\
\text { quality assessment) }\end{array}$ & & 6 \\
\hline \multicolumn{3}{|c|}{$\begin{array}{l}\text { *Signifies that any word beginning with this term would be included in the } \\
\text { search } \\
\text { **The scope of the search for all databases, was } 01.01 .1996-31.12 .2018\end{array}$} \\
\hline
\end{tabular}

\section{Inclusion and Exclusion Criterias}

The criteria used for the studies included in the research were as follows:

- Criterion 1: Time interval: The study was conducted between 1996 and 2018.

- Criterion 2: Source: Refereed/non-refereed journal articles, master theses, and doctoral theses published in selected databases.

- Criterion 3: Appropriate research method in the studies: In order to reach the influence quantity, it was foreseen that the studies to be included should be empirical studies and have branch, gender, and nurse groups.

- Criterion 4: Sufficient numerical data in the studies: Descriptive numerical data were needed to calculate the influence quantity.

The criteria identified for the studies not included in the study were as follows:

- Criterion 1: Congress presentations and announcements.

- Criterion 2: Data previously used in another study (studies converted from a thesis to an article).

- Criterion 3: Lacking in the statistical data required for the meta-analysis.

Table 2. Literature search strategy for relationship between mobbing and job satisfaction

\begin{tabular}{|l|l|l|}
\hline Database & Search terms & Number of Articles \\
\hline Ulusal Tez Merkezi & nurse* and mobbing* and (job or work satifaction) & 42 \\
\hline DergiPark & nurse* and mobbing* and (job or work satifaction) & 4 \\
\hline PubMed & nurse* and mobbing* and (job or work satifaction) & 2 \\
\hline Web of Science & nurse* and mobbing* and (job or work satifaction) & 2 \\
\hline EBSCO Host & nurse* and mobbing* and (job or work satifaction) & 0 \\
\hline Duplicates removed & & 2 \\
\hline Studies retained after both review (YES articles) & & 3 \\
\hline FINAL study selection (after quality assessment) & & 3 \\
\hline $\begin{array}{l}* \text { *Signifies that any word beginning with this term would be included in the search } \\
\text { **The scope of the search for all databases, was 01.01.1996-31.12.2018 }\end{array}$ \\
\hline
\end{tabular}




\section{Search Selection and Outcomes}

As a result of the systematic review, the electronic databases yielded 850 publications for perceived mobbing level and 50 publications for the relationship between mobbing and job satisfaction. Figure 1 and Figure 2 illustrate the search and extraction process. We manually found duplications, thus reducing the search results to 839 publications for perceived mobbing level and 48 publications for the relationship between mobbing and job satisfaction.

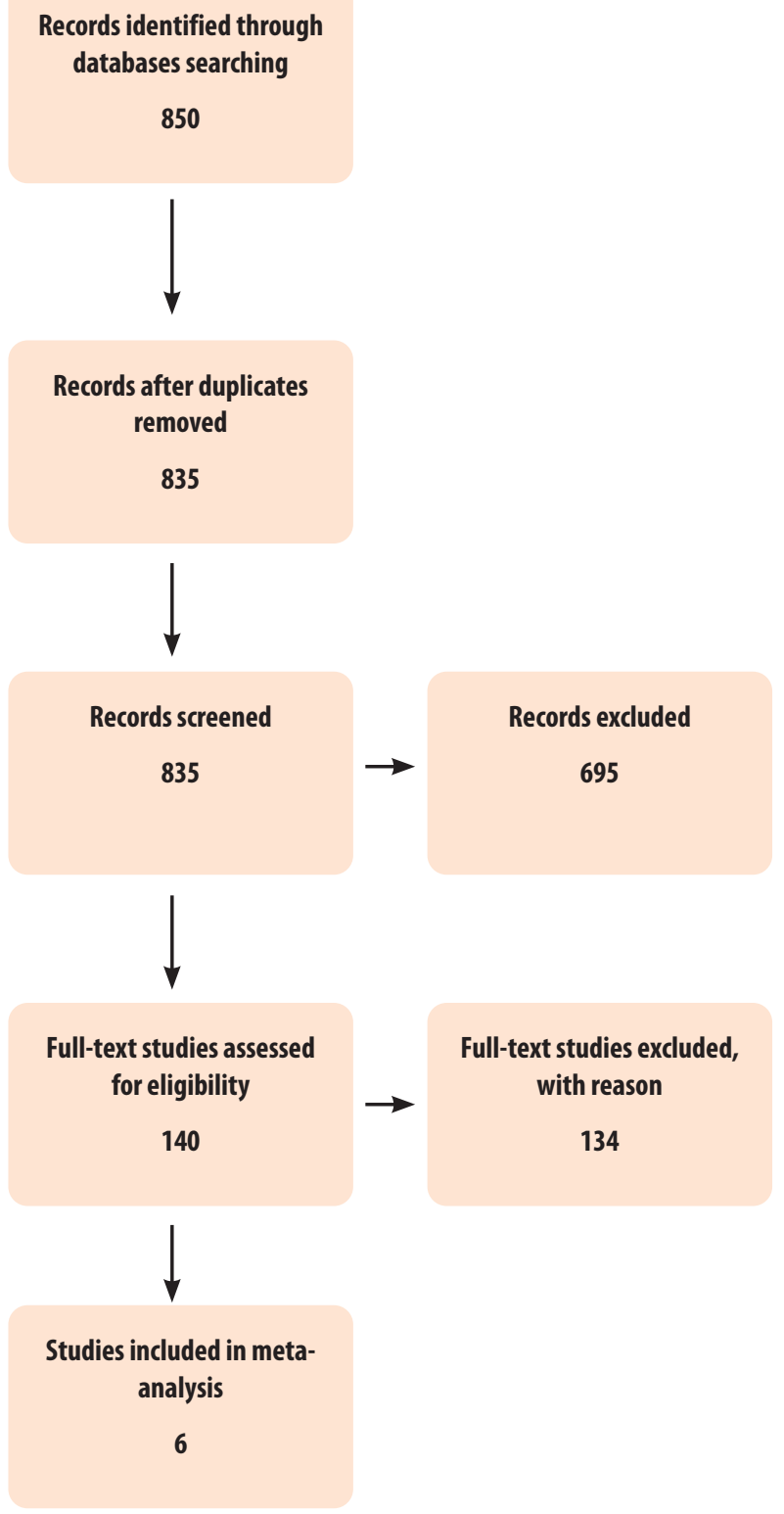

Figure 1. Number of studies to be included in general mobbing perception analysis as a result of systematic screening
We then screened the titles and abstracts of all the records and identified 40 articles that potentially associated with perceived mobbing level and 14 articles that correlated with mobbing and job satisfaction. Following reviewing the articles, we included 6 out of the 40 publications for perceived mobbing level and 3 out of 14 publications for the relationship between mobbing and job satisfaction (see Table 3 and Table 4 for further details).
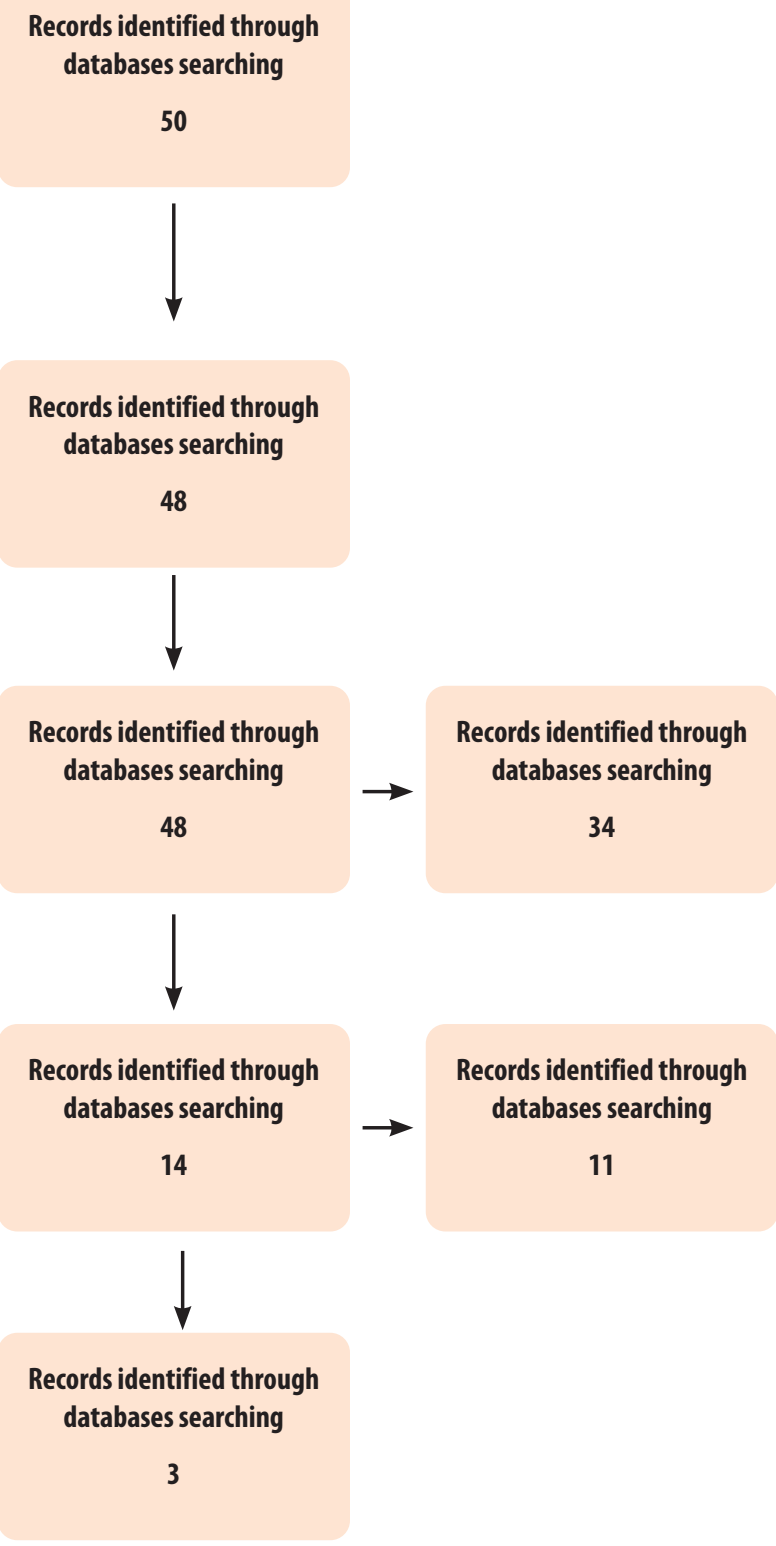

Figure 2. Number of studies to be included in the analysis of the relationship between mobbing and job satisfaction as a result of systematic screening 


\begin{tabular}{|c|c|c|c|c|c|c|}
\hline $\begin{array}{c}\text { Author(s) / } \\
\text { Year }\end{array}$ & Study design & Aim & Subject & Measures & $\begin{array}{l}\text { Reliability } \\
\text { Cronbach } \\
\text { a }\end{array}$ & Analysis \\
\hline $\begin{array}{l}\text { Alar Erkal } \\
(2012)\end{array}$ & Cross-Sectional & $\begin{array}{l}\text { To measure the level of mobbing perception } \\
\text { and the relationship between the } \\
\text { organizational structure and the perception } \\
\text { of mobbing. }\end{array}$ & 309 nurses & LIPT & 0,9591 & $\begin{array}{l}\text { Correlation } \\
\text { analysis, } \\
\text { LSD Post Hoc test, } \\
\text { ANOVA test }\end{array}$ \\
\hline $\begin{array}{l}\text { Gül ve } \\
\text { Ağıröz } \\
\text { (2011) }\end{array}$ & Cross-Sectional & $\begin{array}{l}\text { To measure the level of mobbing } \\
\text { perception, relationship between mobbing } \\
\text { and organizational cynicism and its sub- } \\
\text { dimensions and to contribute to the literature } \\
\text { with quantitative findings based on research. }\end{array}$ & 103 nurses & LIPT & 0,962 & $\begin{array}{l}\text { Correlation } \\
\text { analysis, } \\
\text { Regression }\end{array}$ \\
\hline $\begin{array}{l}\text { Kılıçaslan } \\
\text { ve Kaya } \\
(2017)\end{array}$ & Cross-Sectional & $\begin{array}{l}\text { To measure the level of mobbing perception, } \\
\text { relationships between mobbing and its sub- } \\
\text { dimensions and organizational cynicism and } \\
\text { to contribute to the findings of organizational } \\
\text { behavior literature. }\end{array}$ & 117 nurses & LIPT & NO & Linear regression \\
\hline $\begin{array}{l}\text { Kovar } \\
(2018)\end{array}$ & Cross-Sectional & $\begin{array}{l}\text { To measure the level of mobbing perception, } \\
\text { and determine the relationship between } \\
\text { mobbing behaviors and organizational } \\
\text { culture. }\end{array}$ & 377 nurses & LIPT & 0,960 & $\begin{array}{l}\text { Mann Whitney U } \\
\text { test, } \\
\text { Oneway ANOWA } \\
\text { test, } \\
\text { Tukey HSD test, } \\
\text { Kruskal Wallis test } \\
\text { Correlation } \\
\text { analysis }\end{array}$ \\
\hline $\begin{array}{l}\text { Özdemir } \\
\text { (2014) }\end{array}$ & Cross-Sectional & $\begin{array}{l}\text { To measure the level of mobbing perception, } \\
\text { and relationship between mobbing sub- } \\
\text { dimensions and job satisfaction. }\end{array}$ & 160 nurses & LIPT & 0,951 & $\begin{array}{l}\text { TTest } \\
\text { Correlation } \\
\text { analysis }\end{array}$ \\
\hline $\begin{array}{l}\text { Talas } \\
(2018)\end{array}$ & Cross-Sectional & $\begin{array}{l}\text { To determine the relationship between } \\
\text { mobbing and job satisfaction of nurses. }\end{array}$ & 386 nurses & $\begin{array}{l}\text { LIPT } \\
\text { Minnesota } \\
\text { Job } \\
\text { Satisfaction } \\
\text { Scale }\end{array}$ & $\begin{array}{l}0,94 \\
0,94\end{array}$ & $\begin{array}{l}\text { Kologorov- } \\
\text { Smirnov } \\
\text { Regresyon } \\
\text { OneWay ANOWA } \\
\text { Pearson } \\
\text { Correlation }\end{array}$ \\
\hline
\end{tabular}

\begin{tabular}{|c|c|c|c|c|c|c|}
\hline $\begin{array}{c}\text { Author(s) / } \\
\text { Year }\end{array}$ & Study design & Aim & Subject & Measures & $\begin{array}{l}\text { Reliability } \\
\text { Cronbach } \\
\text { a }\end{array}$ & Analysis \\
\hline $\begin{array}{l}\text { Akbaş, } \\
2009\end{array}$ & Cross-Sectional & $\begin{array}{l}\text { To reveal the importance of mobbing in } \\
\text { working life and the relationship between } \\
\text { mobbing and job satisfaction. }\end{array}$ & 177 nurses & $\begin{array}{l}\text { LIPT } \\
\text { Job } \\
\text { Satisfaction } \\
\text { Scale }^{1}\end{array}$ & $\begin{array}{l}0,927 \\
0,899\end{array}$ & $\begin{array}{l}\text { Correlation } \\
\text { LSD Post Hoc } \\
\text { ANOVA }\end{array}$ \\
\hline $\begin{array}{l}\text { Aydın } \\
\text { (2012) }\end{array}$ & Cross-Sectional & $\begin{array}{l}\text { To evaluate the effect of mobbing behaviors } \\
\text { faced by nurses working at university hospital } \\
\text { on job satisfaction and some variables (age, } \\
\text { marital status, education level, seniority year, } \\
\text { etc.). }\end{array}$ & 301 nurses & $\begin{array}{l}\text { Mobbing } \\
\text { Scale }^{2} \\
\text { Minnesota } \\
\text { Job } \\
\text { Satisfaction } \\
\text { Scale }\end{array}$ & $\begin{array}{l}0,92 \\
0,84\end{array}$ & $\begin{array}{l}\text { Kruskal Wallis } \mathrm{H} \\
\text { Mann Whitney U } \\
\text { Korelasyon } \\
\text { Regresyon }\end{array}$ \\
\hline $\begin{array}{l}\text { Talas } \\
(2018)\end{array}$ & Cross-Sectional & $\begin{array}{l}\text { To determine the relationship between } \\
\text { mobbing and job satisfaction of nurses. }\end{array}$ & 386 nurses & $\begin{array}{l}\text { LIPT } \\
\text { Minnesota } \\
\text { Job } \\
\text { Satisfaction } \\
\text { Scale }\end{array}$ & $\begin{array}{l}0,94 \\
0,94\end{array}$ & $\begin{array}{l}\text { Kologorov- } \\
\text { Smirnov } \\
\text { Regresyon } \\
\text { OneWay ANOWA } \\
\text { Pearson } \\
\text { Correlation }\end{array}$ \\
\hline
\end{tabular}




\section{Quality Appraisal}

All studies were screened for quality in accordance with the published "Quality Assessment and Validity Tool for Correlational Studies" (26). The research quality classified as high (10-14), medium (5-9), or low (0-4) using this tool. The tool consists of 13 questions and consists of a binary answer form in the form of not met or met. 12 questions are scored over 0 (= not met) and 1 (= met); 1 question is scored over 0 (= not met) and 2 (= met). The total of 13 questions is 14 points. See Table 5 .

\section{Data Analysis}

The data obtained was coded using the Comprehensive Meta-Analysis Version 3 software program. The program also was used to calculate the weighted mean and the weighted mean correlation (R) of each article and dissertation. Pearson's correlation coefficient $(r)$ was used to analyze effect size.

Random-effect models were selected on the basis of the possible heterogeneity of the sample groups and methodological characteristics of the included studies. Funnel plots, Fail-Safe $\mathrm{N}$ tests, and the Begg and Mazumdar rank correlation test were used to determine publication bias (27).

\section{RESULTS}

\section{Study Characteristics}

Most of the studies included in this review were rated as high quality, and cross-sectional design was used in all studies. See Table 5 for a summary of the quality assessment of the included studies. See Table 3 and Table 4 for the details. All studies were executed in Turkey, were published between 2009 and 2018, and had a quantitative research design.

Six studies explored perceived mobbing levels (6-7,28$31)$, and three studies searched out the correlation between the mobbing and job satisfaction $(2-3,7)$ of nurses.

\section{Measurement Instruments for Mobbing}

As the perceived mobbing levels were not compared with any variables when analyzed, studies prepared with the same scale were included in the research. The Leymann Inventory of Psychological Terror (LIPT) questionnaire was used in all studies to measure the perceived mobbing level. The LIPT is a scale that includes 45 intimidation behaviors. The frequency of mobbing was scored as $1=$ daily, 2 $=$ at least several times a week, $3=$ several times a month, $4=$ several times a year, and $5=$ never. As the measured value approaches 1 , the mobbing level increases. All five studies reported Cronbach's a reliabilities of $>0.95$. For more information, please check Table 3.

\begin{tabular}{|l|c|c|c|c|c|c|c|c|}
\hline Table 5. Summary of quality assessment & $\begin{array}{c}\text { Akbaş } \\
(2009)\end{array}$ & $\begin{array}{c}\text { Alar Erkal } \\
(2012)\end{array}$ & $\begin{array}{c}\text { Aydın } \\
(2012)\end{array}$ & $\begin{array}{c}\text { Gül and } \\
\text { Ağıröz } \\
(2011)\end{array}$ & $\begin{array}{c}\text { Kılıçaslan } \\
\text { and Kaya } \\
(2017)\end{array}$ & $\begin{array}{c}\text { Kovar } \\
(2018)\end{array}$ & $\begin{array}{c}\text { Özdemir } \\
(2014)\end{array}$ & $\begin{array}{c}\text { Talas } \\
(2018)\end{array}$ \\
\hline Prospectives studies & 0 & 0 & 0 & 0 & 0 & 0 & 0 & 0 \\
\hline Probably sampling & 1 & 1 & 1 & 1 & 1 & 1 & 1 & 1 \\
\hline Appropriate sample size & 1 & 0 & 1 & 0 & 0 & 0 & 0 & 0 \\
\hline Sample drawn from more than one site & 1 & 1 & 0 & 0 & 0 & 1 & 0 & 1 \\
\hline Anonymity protected & 1 & 1 & 1 & 1 & 1 & 1 & 1 & 1 \\
\hline Response rate >60\% & 1 & 1 & 1 & 1 & 0 & 1 & 1 \\
\hline Reliable measure of outcome(s) & 1 & 1 & 1 & 1 & 0 & 1 & 1 & 1 \\
\hline Valid measure of outcome(s) & 1 & 1 & 1 & 1 & 1 & 1 & 1 \\
\hline Valid measure of mobbing & 1 & 1 & 1 & 1 & 1 & 1 & 1 \\
\hline *Mobbing internal consistency & 2 & 2 & 2 & 2 & 2 & 2 & 2 \\
\hline Theoretical framework used & 1 & 1 & 1 & 1 & 1 & 1 & 1 \\
\hline Correlation analysis for multiple effects & 1 & 1 & 1 & 1 & 1 & 1 & 1 \\
\hline Management of outliers addressed & 1 & 1 & 1 & 1 & 1 & 1 & 1 \\
\hline Total score & 13 & 12 & 12 & 11 & 9 & 12 & 1 \\
\hline *Score 2 points & & & & & 1 \\
\hline
\end{tabular}




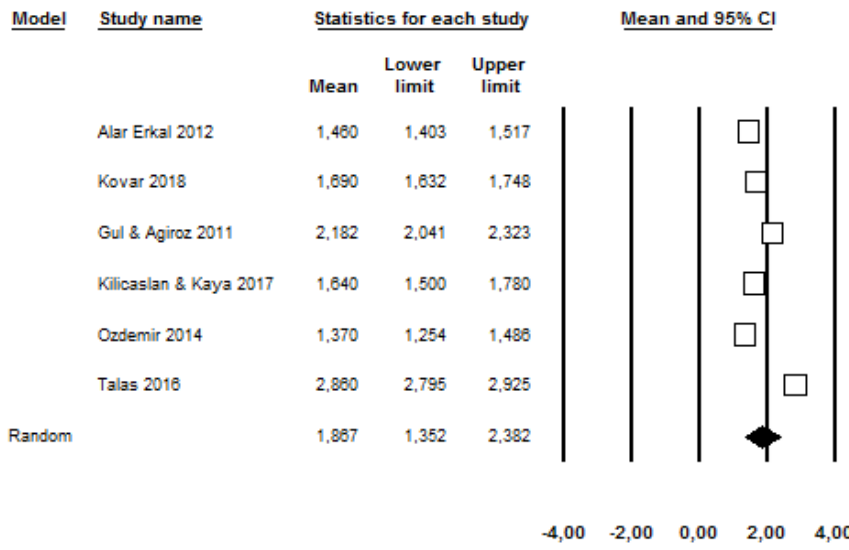

Figure 3. Forest graph results of general mobbing perception
All studies reported Cronbach's a reliabilities of $>0.92$ for mobbing, and of $>0.84$ for job satisfaction. For more information, please check Table 4.

\section{Meta-Analysis of the Perceived Mobbing Level}

All studies in the meta-analysis examined the perceived mobbing level through the LIPT. The perceived mobbing level was high in some studies (35-38), medium in one (39), and low in some $(18,40)$.

The meta-analysis showed that the perceived mobbing level was 1.867 , which is high. Total population of the study was 1.452 , and the $95 \% \mathrm{Cl}$ was $1.352-2.382$. See Figure 3 for details.

The fail-safe number (FSN) value was 9068, which is higher than the recommended tolerance $(5 k+10, k=10)$. The funnel graph in Figure 5 is seen to have partial asymmetry due to a lack of studies. Although standard error values are good, there is partial symmetry. In this case, it can be said that there is partial publication bias. According to the results of the Begg and Mazumdar rank correlation test, which is another test of publication bias, there is no such bias $(p=0.12983)$.

\section{Meta-Analysis of the Correlation Between Mobbing and Job Satisfaction}

All studies in the meta-analysis examined the relationship between the overall perceived mobbing and job satisfaction. Some studies revealed that mobbing is related to job satisfaction (5-6,41-42), whereas other studies reported that mobbing and job satisfaction are not significantly correlated $(22,43)$.

The results showed that mobbing and job satisfaction are significantly negatively correlated $(r=-.510, p=.000)$. Total population of the study was 864 , and the $95 \% \mathrm{Cl}$ was between -.558 and -.458 . See Figure 4 for details.

The FSN value was 204, which is higher than the recommended tolerance. Therefore, the results were contemplated as potent. The funnel graph in Figure 6 is symmetrical, and there is concentration in the peak area of the graph. This is proof that there is no publication bias. ve-point Likert types. On the five-point Likert-type scale, the scores were evaluated as $5=$ strongly agree, $4=$ agree, $3=$ undecided, $2=$ disagree, and $1=$ strongly disagree. 


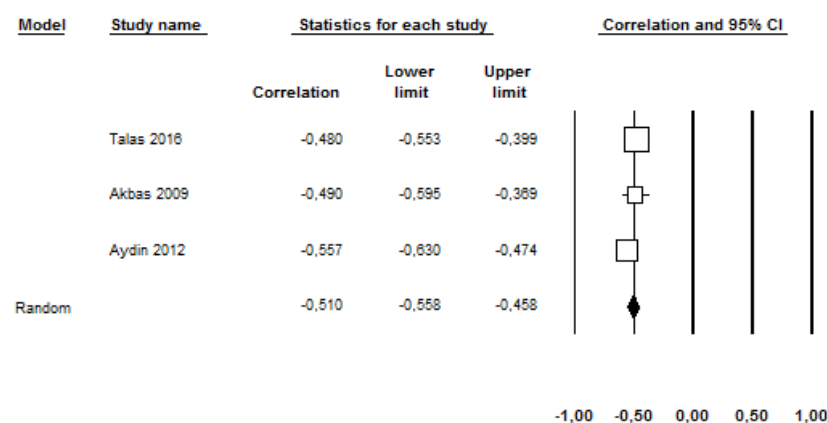

Figure 4. Forest graph results of relationship between mobbing and job satisfaction

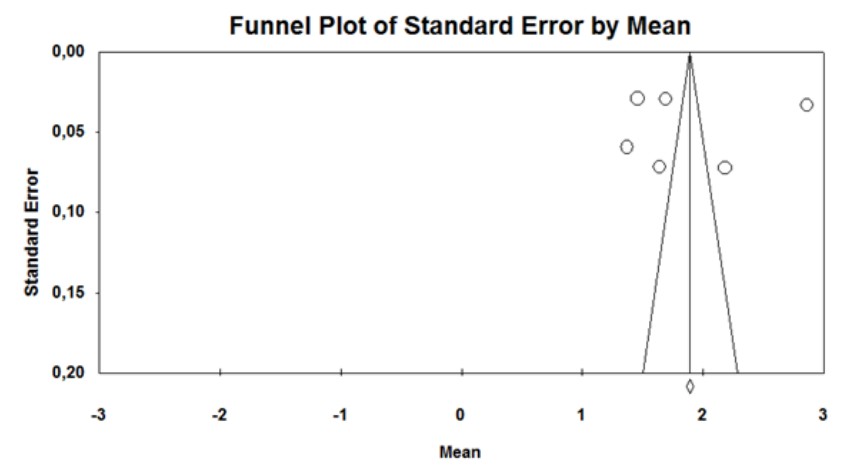

Figure 5. Funnel plot publication bias test of general mobbing perception

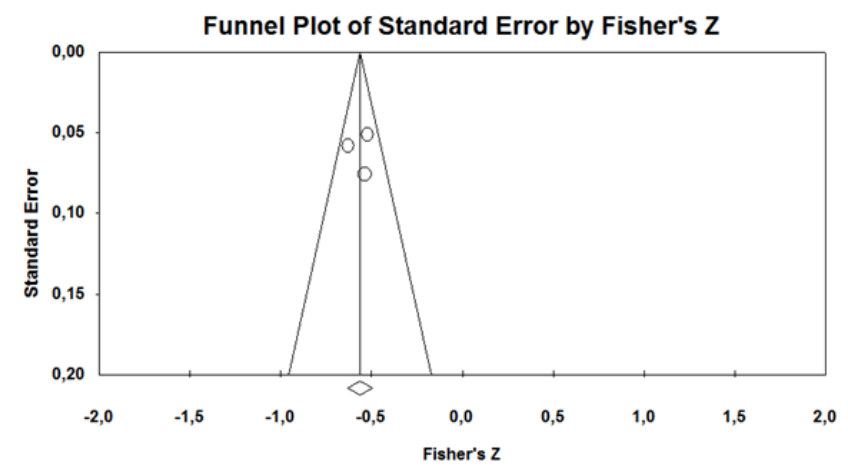

Figure 6. Funnel plot publication bias test of relationship between mobbing and job satisfaction

\section{DISCUSSION}

When the literature is examined, there is a limited number of meta-analysis studies on mobbing. However, in the literature, no meta-analysis study on mobbing, mobbing dimensions, and job satisfaction of nurses has been found.

In this study, perceived mobbing levels, and the relationship between the job satisfaction and mobbing of nurses who work in Turkey, have been examined. Six studies have been added to the perceived mobbing level analysis of nurses, and the number of samples has reached 1,452. Four of them were prepared as master's theses and two of them were prepared as articles. Alar Erkal (28), Kovar (31), Kılıçaslan and Kaya (30), and Özdemir (6) found, in their studies with 309, 377, 117, and 160 nurses, respectively, that the perceived mobbing level of the nurses was between 1.00 and 1.99. This shows that nurses had experienced high levels of mobbing during the last year. In their studies, Gül and Ağıröz (29) with 103 nurses and Talas (7) with 386 nurses found the perceived mobbing level of nurses to be between 2.00 and 2.99. Although not as much as the other studies included in the analysis, the results of these studies also indicate that nurses are exposed to high levels of mobbing. As a result of the meta-analysis, the perceived mobbing level of nurses was calculated as 1.867 ( $p=0.000$ ). So, we can say that nurses encounter very high levels of mobbing in Turkey.

Topa and Moriano (44) measured the mobbing levels of 388 nurses with the Negative Behavior Scale prepared by Einarsen and Raknes in 1997. As a result of the study, the mobbing average of nurses was calculated as 1.51 . According to the Negative Behavior Scale, this ratio shows that nurses are almost never exposed to mobbing, but it is reported that $75 \%$ of nurses have been exposed to mobbing behavior by their colleagues in the last 6 months. Aydın (3) measured the mobbing levels of nurses with the Mobbing Scale developed by Yıldırım and Yıldırım in 2008 on 301 nurses working in a university hospital in Istanbul. As a result of the study, the average mobbing level of the nurses was calculated as 0.947 . According the scale used, if this value is less than 1 , it shows that nurses are not deliberately exposed to mobbing. According to the study by Aydın (3), nurses are exposed to mobbing behaviors to a serious extent, if not intentionally.

Qunie (45) aimed to measure mobbing levels by using the Hospital Anxiety and Depression Scale prepared by Zigmond and Snaith in 1983 on 1,100 health care workers (396 nurses) in the UK. It was shown that $44 \%$ of the 
nurses were exposed to mobbing behaviors, and nurses were exposed to more mobbing behaviors than other health care workers (mobbing average of nurses $=2.2$, mobbing average of other health care workers $=1.5$ ).

Yıldırım and Yıldırım (46) observed that $86.5 \%$ of nurses were exposed to mobbing behaviors, and Yıldırım (47) observed that $21 \%$ of nurses had been exposed to mobbing behaviors in the last year. Pınar, et al (48) calculated the mobbing exposure of health care workers as $15 \%$ in their study on 12,944 health care workers (4,343 nurses). As a result of their meta-analysis, Dalvand et al (49) found that the mobbing rate of 5,639 nurses in Iran was $28 \%$.

In their studies, Talas (7) with 386 nurses, Akbaş (2) with 177 nurses, Aydın (3) with 301 nurses, Goris et al (50) with 446 nurses, Aiken et al (51) with 84 nurses, Özdemir (6) with 160 nurses, Gökdemir (5) with 277 nurses, and Quine (45) with 1,100 health workers (396 nurses) found a negative correlation between job satisfaction and mobbing. So, there is an inverse relationship between mobbing and job satisfaction. As one increases, the other decreases. No scale limitation was applied when examining the relationship between mobbing and job satisfaction. Three studies were added to this analysis, and the number of samples reached 864 . As a result of the analysis, the correlation value of the relationship between mobbing and job satisfaction was calculated as $-.510(p=.000)$. As mobbing levels of nurses in Turkey increase, job satisfaction levels decrease.

In the literature, the perceived mobbing levels that nurses are exposed to varies. In line with the studies included in the meta-analysis research, it was determined that nurses are exposed to high levels of mobbing in Turkey. A negative relationship was observed in all studies in the field of job satisfaction and mobbing. In this study, this relationship was found to be negative, in parallel with the other results.

\section{CONCLUSION}

The perceived mobbing level, according to the metaanalysis, were found to show that nurses are exposed to a high degree of mobbing behavior in Turkey. The relationship between mobbing and job satisfaction showed a negative and moderate correlation. In other words, as the mobbing level increases, the job satisfaction level decreases.
Since individuals spend about one-third of their lives working in the workplace, satisfaction from work will increase the quality of the individual in his or her working life and therefore the level of satisfaction he or she will feel from his or her social life. The negative consequences of the negative relationship between mobbing and job satisfaction affect not only the individual's social life but also many variables such as the success, performance, and profit ratio of the organization. For this reason, managers are expected to take care to keep the job satisfaction levels of their employees high. It is necessary to identify the employees who have problems by the managers, to guide them and create a fair and friendly working environment.

\section{Limitations}

This study has several limitations. Nurses who are only working in Turkey were included in this study. Studies published in Turkish and English were used.

\section{Author Contributions:}

In this study, MK and GO established the study design, determined the inclusion and exclusion criteria, and made meta-analysis with the obtained data. MK systematically scanned through online databases, screened according to specified inclusion and exclusion criteria, scored study based on quality evaluation criteria. $\mathrm{GO}$ also checked all the steps of the study. All authors have agreed on the final version.

\section{Conflict of Interest:}

The authors declare that they have no conflict of interests.

\section{Funding}

This study was supported by Ondokuz Mayıs University Scientific Research Project Unit with project number PYO. SBF.1904.19.001.

\section{Note}

This study was prepared from Mustafa KURNAZ's master thesis titled “Hemşirelerde Mobbing ve Iş̧ Tatmini Illişkisinin Meta Analiz Yöntemiyle İncelenmesi (Assessment of Mobbing And Job Satisfaction Relationship With MetaAnalysis Method in Nurses)" under the supervision of Asst. Prof. Gülpembe OĞUZHAN. All data of the study can be accessed from https://tez.yok.gov.tr/UlusalTezMerkezi/giris.jsp website with the code 575251. 


\section{REFERENCES}

1. Çivilidağ A and Sargın N. Academics' mobbing and job satisfaction levels. TOJCE 2013;2(2):55-66.

2. Akbaş $\mathrm{S}$. İşyerinde psikolojik şiddet (mobbing) ve iş tatmin ilişkisi: Sağlık çalışanları üzerine bir uygulama. (Master Dissertation). Retrieved from Ulusal Tez Merkezi. (235796). 2009:63-100.

3. Aydın Y. Bir üniversite hastanesinde çalışan hemşirelerin karşılaştıkları yıldırıcı davranışlar ile iş doyumu arasındaki ilişki. (Master Dissertation). Retrieved from Ulusal Tez Merkezi. (324188). 2012:37-72.

4. Erdoğan V and Yıldırım A. Healthcare professionals' exposure to mobbing behaviors and relation of mobbing with job satisfaction and organizational commitment. Procedia Comput Sci 2017;120:931-8

5. Gökdemir D. Sağlık çalışanlarında mobbing algısının iş tatmini üzerindeki etkisi: Kamu hastanesinde bir araştırma. (Master Dissertation). Retrieved from Ulusal Tez Merkezi. (443140). 2016:72-142.

6. Özdemir S. Mobbing ve iş doyumu ilişkisi (Hemşireler üzerine bir araştırma). (Master Dissertation). Retrieved from Ulusal Tez Merkezi. (361961). 2014:48-101.

7. Talas Ş. Hemşirelere uygulanan mobbing ile iş doyumu arasındaki ilişkinin incelenmesi. (Master Dissertation). Retrieved from Ulusal Tez Merkezi. (443126). 2016:33-65.

8. Leymann H. Mobbing and psychological terror at workplaces. Violence Vict 1990:5(2):119-26.

9. Baron RA and Neuman JH. Workplace violence and workplace aggression: Evidence on their relative frequency and potential causes. Aggress Behav 1996:22(3);161-73.

10. Björkqvist $\mathrm{K}$, Österman $\mathrm{K}$ and Hjelt-Back $\mathrm{M}$. Aggression among university employees. Aggress Behav 1994:20(3);173-84.

11. Hoel $\mathrm{H}$ and Cooper $\mathrm{C}$. Destructive conflict and bullying at work. Manchester: Manchester School of Management, UMIST. 2000:1-30.

12. O'Moore M, Seigne E, McGuire L, et al. Victims of workplace bullying in Ireland. Ir J Psychol 1998:19(2-3);345-57.

13. Zapf D. Organisational, work group related and personal causes of mobbing/bullying at work. Int J Manpow 1999:20(1-2);70-85.

14. Asi Karakaş $S$ and Okanlı A. Hemşirelik ve mobbing. Gumushane University Journal of Health Science 2013:2(4);562-76.

15. Kılıç T, Çiftçi $F$ and Şener Ş. Sağlık çalışanlarında mobbing ve ilişkili faktörler. Journal of Health and Nursing Management 2016:2(3);65-72.

16. Kingma M. Workplace violence in the health sector: A problem of epidemic proportion. International Nursing Review 2001:48(3);129-30.

17. Yiğitbaş, Ç.ı \& Deveci, S. E. (2015). Sağlık çalışanlarına yönelik mobbing. Mesleki Sağlık ve Güvenlik Dergisi (MSG) 2015:11(42);23-28.

18. Açıl İ. Mobbingin hemşirelerde mesleki bağlılığa etkisi. (Master Dissertation). Retrieved from Ulusal Tez Merkezi. (486216). 2017:5-27.

19. Aslan N. Hemşirelerin mizah tarzları ile stres düzeyleri arasındaki ilişkinin belirlenmesi. (Master Dissertation). Retrieved from Ulusal Tez Merkezi. (474468). 2017:5-15.

20. Cumbey DA and Alexander JW. The relationship of job satisfaction with organizational variables in public health nursing. J Nurs Adm 1998:28(5);39-46.

21. Kirkcaldy BD and Martin T. Job stress and satisfaction among nurses: Individual differences. Stress Medicine 2000:16(2);77-89.

22. Teker SK. Mobbingin iş tatminine etkisinin belirlenmesine yönelik bir araştırma: Sağlık kurumu örneği. (Master Dissertation). Retrieved from Ulusal Tez Merkezi. (357767). 2014:1-6.
23. Kavak A. Sağlık çalışanlarında mobbing ve iş tatmini (Ardahan İli örneği). (Master Dissertation). Retrieved from Ulusal Tez Merkezi. (529231). 2018:30-34.

24. Kış A. Okul müdürlerinin öğretimsel liderlik davranışlarını gösterme düzeylerine ilişkin yönetici ve öğretmen görüşlerine yönelik bir meta-analiz. (Doctoral Dissertation). Retrieved from Ulusal Tez Merkezi. (350925). 2013:20-87.

25. Joanna Briggs Institute. The Joanna Briggs Institute Critical Appraisal tools for use in JBI Systematic Reviews. Checklist for systematic reviews and research syntheses. 2017. Retreived from https://joannabriggs.org/sites/default/files/2019-05/JBI_Critical_ Apprai sal-Checlist_for_Systematic_Reviews2017_0.pdf on 02 March 2019.

26. Cicoloni G, Comparcini D and Simonetti V. Workplace empowerment and nurses' job satisfaction: a systematic review. J Nurs Manag 2004:22(7);855-71.

27. Higgins JP, Thompson SG, Deeks JJ, et al. Measuring inconsistency in meta-analysis. BMJ 2003:327(7414);557-60.

28. Alar Erkal E. Örgüt kültürü özelliklerinin hemşirelerinin psikolojik taciz algısı üzerindeki rolü: Kamu sektörü örneği. (Master Dissertation). Retrieved from Ulusal Tez Merkezi. (319790). 2012:61-99.

29. Gül H and Ağıröz A. Mobbing ve örgütsel sinizm arasındaki ilişkiler: Hemşireler üzerinde bir uygulama. Afyon Kocatepe University Journal of Economics and Administrative Sciences 2011:13(2);27-47.

30. Kılıçaslan S and Kaya A. Mobbingin örgütsel sinizm üzerine etkisi hemşireler üzerinde bir uygulama. Journal of Suleyman Demirel University Institute of Social Sciences 2017:25(1);9-25.

31. Kovar M. Kamu ve üniversite hastanelerinde çalışan hemşirelerin algıladıkları mobbing davranışları ve örgüt kültürü arasındaki ilişkinin belirlenmesi. (Master Dissertation). Retrieved from Ulusal Tez Merkezi. (517205). 2018:33-78.

32. Yıldırım A and Yıldırım D. (2008). Development and psychometric evaluation of workplace violent behaviours instrument. J Clin Nurs 2008:17(10);1361-70.

33. Weiss DJ, Rene VD and George WE. Manuel for the Minnesota satisfaction questionnaire. Minnesota studies in vocational rehabilation. 1967.

34. Comer JM, Machleit KA and Lagace RR. Psychometric assessment of a reduced version of INDSALES. J Bus Res 1989:18;291-302.

35. Demir E. İş yaşamında mobbing. (Master Dissertation). Retrieved from Ulusal Tez Merkezi. (419558). 2014:88-162.

36. Pala B. Cerrahi kliniklerde çalışan hemşirelerin mobbing yaşama durumlarının hemşirelik bakım kalitesine etkisi. (Master Dissertation). Retrieved from Ulusal Tez Merkezi. (520371). 2018:41-59.

37. Saraç E. Hemşirelerde mobbingin anksiyete düzeyi ile ilişkisi. (Master Dissertation). Retrieved from Ulusal Tez Merkezi. (498212). 2018:45-62.

38. Taştan T. Hemşirelikte mobbing yaşama durumunun kurumsal bağlılık ve kurumsal güvene etkisi. (Master Dissertation). Retrieved from Ulusal Tez Merkezi. (454085). 2017:22-32.

39. Akyol Aydın F. Ameliyathane hemşirelerinde mobbing ve tükenmişlik düzeylerinin incelenmesi. (Master Dissertation). Retrieved from Ulusal Tez Merkezi. (518416). 2018:36-60.

40. Bardakçı E. Bir üniversite hastanesinde çalışan hemşirelerin yaşadığı mobbingin ruhsal sağlıklarına etkisi. (Master Dissertation). Retrieved form Ulusal Tez Merkezi. (361319). 2014:17-29.

41. Ünlüsoy Dinçer N. Hemşirelerin işyeri şiddetine maruz kalma durumları ile iş doyumları ve işten ayrılma eğilimleri. (Doctoral Dissertation). Retrieved from Ulusal Tez Merkezi. (267388).2010:56-134. 
42. Yıldız E. Hastanelerde kadın çalışanlara yönelik psikolojik yıldırma (mobbing) ve iş tatminine etkisi: Isparta ilinde bir uygulama. (Master Dissertation). Retrieved from Ulusal Tez Merkezi. (395948). 2015:77-108.

43. Temur Ö. Psikolojik şiddet uygulamalarının çalışanların iş tatminine etkisi: Eskişehir İl Sağlık Müdürlüğü örneği. (Master Dissertation). Retrieved from Ulusal Tez Merkezi. (228885). 2009:106-22.

44. Topa $G$ and Moriano JA. Stress and nurses' horizontal mobbing: Moderating effects of group identity and group support. Nur Outlook 2013:61(3);e25-e31.

45. Quine L. Workplace bullying in nurses. J Health Psychol 2001:6(1);73-84.

46. Yıldırım A and Yıldırım D. (2007). Mobbing in the workplace by peers and managers: Mobbing experienced by nurses working in healthcare facilities in Turkey and its effect on nurses. J Clin Nurs 2007:16(8);1444-53.

47. Yıldırım D. Bullying among nurses and its effects. International Nursing Review 2009:56(4);504-11.

48. Pınar T, Açıkel C, Pınar G, et al. Workplace violence in the health sector in Turkey: a national study. J Interpers Violence 2017:37(15);2345-65.

49. Dalvand S, Gheshlagh RG, Najafi F, et al. The prevalence of workplace against Iranian nurses: A systematic review and metaanalysis. Shiraz E-Medical J 2018:19(9);1-8.

50. Goris S, Ceyhan Ö, Taşçı S, et al. Mobbing against nurses in Turkey: How does it affect job satisfaction?. Int J Caring Sci 2016:9(3);810-8.

51. Aiken LH, Clarke SP, Sloane DM, et al. Hospital nurse stafing and patient mortality, nurse burnout, and job dissatisfaction. JAMA 2002:288(16);1987-93. 